\title{
The effects of prolonged exposure to high glucose on glucose metabolism and metabolomic profiles in pancreatic $\beta$-cells
}

\author{
M. Wallace and L. Brennan \\ UCD School of Agriculture, Food Science and Veterinary Medicine, Conway Institute, University College Dublin, \\ Dublin 4, Republic of Ireland
}

Diabetes mellitus affects $>180$ million individuals worldwide ${ }^{(1)}$. Type 2 diabetes is characterised by impaired insulin secretion from pancreatic $\beta$-cells and increased insulin resistance in peripheral tissues resulting in hyperglycaemia. Long-term exposure to high glucose concentrations has been shown to cause pancreatic $\beta$-cell apoptosis ${ }^{(2)}$, impaired insulin secretion ${ }^{(3)}$ and impaired mitochondrial function ${ }^{(4,5)}$. The resulting glucotoxicity is thought to be a contributing factor to the deterioration of pancreatic $\beta$-cell function and mass, which leads to progression of the disease. The current study used the novel approach of combining flux analysis and metabolomic profiling to investigate the effects of high glucose levels on metabolic pathways and thus enhance the understanding of the mechanisms of glucotoxicity.

BRIN-BD11 cells were cultured for $20 \mathrm{~h}$ with 11.1 or $25 \mathrm{~mm}$-glucose. Following treatment cells were incubated in $1.1 \mathrm{~mm}$-glucose for $20 \mathrm{~min}$ and then stimulated with $14 \mathrm{~mm}$-glucose for $1 \mathrm{~h}$. Metabolic extracts of the cells were then prepared and ${ }^{1} \mathrm{H}$ NMR spectra were obtained. Glucose uptake and insulin secretion were determined from the media. Flux studies were performed under similar conditions using $\left[\mathrm{U}_{-}{ }^{13} \mathrm{C}\right]$ glucose and ${ }^{13} \mathrm{C}$ NMR spectra were obtained.

Following prolonged exposure to $25 \mathrm{~mm}$-glucose there was a significant decrease in glucose-stimulated insulin secretion (ng/mg protein) from 35.1 (SD 1.2) to 29.5 (SD 2.5; $P<0.03$ ) and a significant decrease in glucose uptake ( $\mu \mathrm{mol} / \mathrm{mg}$ protein) from 37.7 (SD 4.9 ) to 32.6 (SD 4.8; $P<0.05$ ), indicating mild glucotoxicity. Principle component analysis of the ${ }^{1} \mathrm{H}$ NMR spectra showed a distinct separation between the high-glucose-treated group and the control group (11.1 mM-glucose). Preliminary interrogation of the corresponding loadings plot identified alanine and aspartate as being decreased and $\gamma$-aminobutyric acid and glycine as being increased in the high-glucose-treated group. Previous studies have shown that alanine has a potentiating effect on glucose-stimulated insulin secretion and undergoes substantial metabolism in BRIN-BD11 $\beta$-cells ${ }^{(6)}$, whereas $\gamma$-aminobutyric acid production has been associated with a negative effect on insulin secretion ${ }^{(7)}$. Flux analysis of the ${ }^{13} \mathrm{C}$ NMR spectra showed that following prolonged exposure to high glucose levels the amount of ${ }^{13} \mathrm{C}$ label at glutamate $\mathrm{C} 4$ decreased significantly from $33.8 \mathrm{nmol} / \mathrm{mg}$ protein to $27.7 \mathrm{nmol} / \mathrm{mg}$ protein $(P<0.05)$ and the percentage acetyl$\mathrm{CoA}$ that was labelled also decreased. These changes are indicative of a reduction in flux through pyruvate dehydrogenase into the TCA cycle.

Overall, these results show that exposure to high glucose levels cause changes in metabolic flux into the TCA cycle and production of certain key amino acids. The novel combination of metabolic flux and metabolomic analyses gives an enhanced understanding of the underlying mechanisms of glucotoxicity. Future experiments will be directed at expanding this knowledge further and investigating the effects of a combination of high glucose and high lipid exposure.

1. World Health Organization (2006) Diabetes. http://www.who.int/mediacentre/factsheets/fs $312 / \mathrm{en} / \mathrm{index} . \mathrm{html}$

2. Kim WH, Lee JW, Suh YH, Hong SH, Choi JS, Lim JH, Song JH, Gao B \& Jung MH (2005) Diabetes 54, $2602-2611$.

3. Eizirik DL, Korbutt GS \& Hellerstrom C (1992) J Clin Invest 90, 1263-1268.

4. Krauss S, Zhang CY, Scorrano L, Dalgaard LT, St-Pierre J, Grey ST \& Lowell BB (2003) J Clin Invest 112, 1831-1842.

5. Patane G, Anello M, Piro S, Vigneri R, Purrello F \& Rabuazzo AM (2002) Diabetes 51, 2749-2756.

6. Brennan L, Shine A, Hewage C, Malthouse JP, Brindle KM, McClenaghan N, Flatt PR \& Newsholme P (2002) Diabetes 51, 1714-1721.

7. Dong H. Kumar M, Zhang Y et al. (2006) Diabetologia 49, 697-705. 